Journal of Applied Pharmaceutical Science Vol. 5 (11), pp. 146-150, November, 2015

Available online at http://www.japsonline.com

DOI: $10.7324 / \mathrm{JAPS} .2015 .501124$

ISSN 2231-3354 (cc) BY-NC-SA

\title{
Analgesic effect of honey bioactive compounds and its role in reducing morphine tolerance
}

\author{
Nur Husna Zakaria ${ }^{1}$, Nor Zidah Ahmad ${ }^{1}$, Siti Norhajah Hashim ${ }^{1}$, Liyana Hazwani Mohd Adnan ${ }^{1}$, Mohamad Halim \\ Mohamad Shariff ${ }^{1}$, Nasir Mohamad ${ }^{2}$, Khairi Che Mat ${ }^{1}$, Nor Hidayah Abu Bakar ${ }^{1}$ \\ ${ }^{1}$ Faculty of Medicine, Universiti Sultan Zainal Abidin (UniSZA), 20400 Kuala Terengganu, Terengganu Darul Iman, Malaysia. \\ ${ }^{2}$ UniSZA Medical Centre,Universiti Sultan Zainal Abidin (UniSZA), Gong Badak Campus, 21300 Kuala Terengganu, Terengganu Darul Iman, Malaysia.
}

\section{ARTICLE INFO \\ Article history: \\ Received on: 29/08/2015 \\ Revised on: 20/09/2015 \\ Accepted on: 11/10/2015 \\ Available online: 27/11/2015}

Key words:

Honey, bioactive compound,

analgesic, morphine

tolerance.

\begin{abstract}
Honey has been used as a supplement nutrient in human for centuries. It exerts antibacterial, anticancer, antiinflammatory properties as well as analgesic activity. But not many studies have been done to analyze effect of honey on morphine tolerance. Hence, this review is targeting on analgesic effect of honey bioactive compounds and their potential in morphine tolerance study.
\end{abstract}

\section{INTRODUCTION}

Honey is a natural supersaturated solution of sugars produced by honeybees. There are different types of honey mainly Manuka, acacia, Gelam, Tualang, rosemary, heather, New Zealand, Australian, Turkish and chestnut honey (Pyrzynska and Biesaga, 2009) with different physical and chemical properties. Honey mainly consists of carbohydrate(95-98\% of dry weight), proteins, minerals and vitamins (White, 1962; White Jr., 1980). As natural liquid, it also contain phenolic acids, flavonoids and alkaloids (Manyi-Loh et al., 2011). Carbohydrates, the compound that give main energy source in honey are mainly fructose and galactose, followed by minor constituent of mono-, di- and trisaccharides and oligosaccharides (Sato and Miyata, 2000). In other word, honey contains both complex and simple

\footnotetext{
* Corresponding Author

Nasir Mohamad, UniSZA Medical Centre,Universiti Sultan Zainal Abidin (UniSZA), Gong Badak Campus, 21300 Kuala Terengganu,

Terengganu Darul Iman, Malaysia.

Email: drnasirmohamadkb@yahoo.com
}

sugars. Honey can be found in major places of the world. Ancient history marks honey as food and natural remedy used by people in world civilization such as Greeks, Egyptians, Chinese, Romans and Babylonians (Richard, 2009). Today, honey is used for same purposes, traditionally or in modern way.

\section{Bioactive compounds and medicinal properties of honey}

Beside sugar as the major content, honey is accumulated with various bioactive compounds which are phenolic acids and flavonoids. Gallic, syringic, benzoic, trans- cinnamic ,p-coumaric and caffeic acids are phenolic acids of honey while catechin, kaempferol, naringenin, luteolin and apigenin and chrysin are the flavonoids (Pyrzynska and Biesaga, 2009). The flavonoids and phenolic acids are known sources of antioxidants that act as free radical scavengers (Johnston et al., 2005). Flavonoid also involved in many biological properties such as antibacterial, antiinflammatory and anti-allergic activities (Gheldof et al., 2002). These properties contribute to medicinal values of honey. Many studies suggested honey as good source of natural antioxidants (Ahmed et al., 2007). 
More interestingly, honey has same antioxidant activity as in vegetables and fruits based on fresh weight (Gheldof and Engesth, 2002). This important properties contribute to health benefits of honey.

Traditionaly, honey is used to heal wound, sore throat, cough, cold, stomach ulcer and athma (Pyrzynska and Biesaga, 2009; Alzubier and Okechukwu, 2011; Mayer et al., 2014). Past and recent researches proved numerous medicinal properties of honey. Other than its power as healing agent, honey play a big role as antimicrobial agent. Manuka and Ulmo honey was shown to give protective effect against Staphylococcus aureus, Escherichia coli and Pseudomonas aeruginosa (Sherlock et al., 2010). Antibacterial properties of honey are also widely studied. Sesamun indicum, honeydew and Turkish blossom honey are examples that posses antibacterial activities (Tornuk et al., 2013; Das et al., 2015; Mayer et al., 2014). On top of that, honey also possesses anti-allergic, anti-inflammatory, antimutagenic, antitumor, antidiabetic and anticancer (Fauzi et al., 2011) activities. All of these properties have characterized honey as a versatile natural remedy.

\section{Analgesic effects of honey and potentials in morphine tolerance study}

On top of those medical properties widely studied, honey also can act as analgesic agent which is also contributed from its bioactive compounds. Many researchers discovered significant analgesic effects of raw honey (Abdul Aziz et al., 2013; AlvarezSuarez et al., 2013; Owoyele et al., 2011). For instance, mad honey was found to have analgesic effect which is useful in treating painful diabetic neuropathy (Gunduz et al., 2014). Postoperative pain and analgesic requirement also can be reduced by postoperative honey administration (Boroumand et al., 2013). In addition 100, 200 and $500 \mathrm{mg} / \mathrm{kg}$ sidr honey demonstrated dose dependent analgesic effect in acetic acid, formalin writhing test and several other analgesic tests, which prove the honey as a strong analgesic agent (Alzubier and Okechukwu, 2011). However, to date, there are very few studies that relate honey with drug addiction.

Morphine is a commonly used drug in management of acute and chronic pain (Mao et al., 2002). Among uses of morphine as analgesic is before surgery, regional anaesthesia and joint pain. However, in morphine abuse, repeated administration of morphine leads to morphine tolerance (Skrabalova et al., 2013). Morphine tolerance is a condition in which, the analgesic effect of the drug in the body decreased, causing a higher dose is needed to obtain same analgesic effect (Mayer and Mao, 1999). The analgesic effect of morphine takes part on $\operatorname{mu}(\mu)$ opioid receptor (MOR), a G protein-coupled receptor (GPCR) on neuron cells. Binding of morphine on MOR causes activation of the $G$ protein and inhibition of adenylyl cyclase. Release of cyclic adenosine monophosphate (cAMP) reduced, causing inhibition of $\mathrm{Ca}+$ and $\mathrm{Na}+$ channels, resulting in analgesia (Kosten and George, 2002; Lees and Lingford-Hughes, 2012; DuPen et al., 2007). However in morphine tolerance, the mechanism is still unclear. Nowadays, study suggests opioid receptor desensitization and down regulation as two theories that can explain the phenomenon (DuPen et al., 2007). The desensitization of opioid receptor in brain may occur due to prolonged exposure to opioids, by alteration of GPCR (Yoburn et al., 2003). Meanwhile, the downregulation of opioid receptor is may due to its internalization by endocytosis, which causes the receptor to be drawn into intracellular environment of neuron cell (Narita et al., 2006). Furthermore, previous studies also demonstrated that morphine tolerance leads to increase in oxidative stress (Skrabalova et al., 2013). In search for the cure, scientists revealed several cellular processes and conditions that occur in morphine tolerance.

Morphine tolerance among chronic morphine users leads to their continuous needs to morphine administration. To date, methadone therapy is used as a treatment for their morphine addiction (Mohamad et al., 2014). However, methadone substitution therapy did not cure tolerance toward morphine. Besides, uses of methadone can cause side effects such as nausea, numbness, insomnia, muscle pain and sexual dysfunction (Goldberg, 2014). Uses of methadone can also lead to addiction, as methadone is addictive. Therefore, a non addictive substance such as honey would potentially functions to reduce morphine tolerance by its various biological properties.

Bioactive compounds such as phenolic acids and flavonoids can give antinociception or analgesic effect. However, not all the compunds that showed analgesic effects participate in opioid system. For example, baicalin demonstrated significant analgesic effect under chemical antinociception in mice, but the mechanism that modulate the analgesic effect seems not involved opioid receptor (Meotti et al., 2006). On the other side, several compounds were found to involve with opioid system, as their analgesic effects were inhibited by opioid receptor antagonists (Berrocoso et al., 2009). Hence, in this review we explore the honey analgesic properties and their roles in treating morphine tolerance by looking through its phenolic acids and flavonoids.

For instant, gallic acid is one of common phenolic acid found in honey. It is the most abundant bioactive compound in Malaysian Tualang honey after the flavonoid catechin (Khalil et al., 2011) and also can be found in Australian eucalyptus New Zealand Leptospermum, Acacia, lime, chestnut and heather honey (Pyrzynska and Biesaga, 2009). To date, there are no attempt to relate gallic acid with analgesic and antinociception. However, its derivative gallic acid ethyl ester, was found to cause no significant effect in pain response (Santos et al., 1999).

Ellagic acid, not just contain in fruits and vegetables but also found in Australian eucalyptus, New Zealand and Australian Leptospermum, thyme, rosemary, orange and sunflower honey (Pyrzynska and Biesaga, 2009). Acetic acid writhing test using ellagic acid $(0.3-10 \mathrm{mg} / \mathrm{kg})$ showed significant analgesic effect. Furthermore, $1-10 \mathrm{mg} / \mathrm{kg}$ ellagic acid was found to have analgesic activity in hot plate test. This test use short thermal(heat) stimulus and can be applied in assessing central antinociception (Kruger, 2001; Schildhaus et al., 2014). Thus, compound that give high analgesic effect in hot plate test can be classified as strong 
analgesic (Vidyalakshmi et al., 2010). In addition, this dose also possessed important analgesic properties, in which coadministration with morphine significantly blocked development of morphine tolerance (Mansouri et al., 2014). However, the potential of ellagic acid in treating opioid addiction is still elusive. The reason is because, in this study, it is demonstrated that repeated administration of ellagic acid caused decrease in antinociception and development of tolerance. As the action of ellagic acid on opioid receptor is not confirmed, there are several factors that contribute to the analgesic effect and attenuation of morphine tolerance development. First, Ellagic acid may interact with endogenous opioids such as endorphins, enkephalins and dynorphins, leading to analgesic tolerance after repeated administration. Plus, the role of ellagic acid as free radical scavenging agents is another property that led to attenuation of morphine tolerance (Abdel-Zaher et al., 2010). Thus we cannot claim that the attenuation of morphine tolerance was due to action of ellagic acid on mu opioid receptor. Moreover, antidepressant-like activity of ellagic in mice was also found not related to opioid system (Mansouri et al., 2015).

Not only contain in honey, caffeic acid are commonly found in fruits and grains. It is known for its anti-inflammatory properties (Chao et al., 2009; Liu et al., 2014). In a study of inflammatory pain, caffeic acid administered orally by mice showed significant analgesic effect in acetic acid-induced writhing test at doses 5, 10, 30 and 100mg/kg (Mehrotra et al., 2011). Tail flick and hotplate test did not show significant thermal antinociception at 30,100 and $200 \mathrm{mg} / \mathrm{kg}$ compared to vehicle treated group. However, in another study of analgesic activity, 10 $\mathrm{mg} / \mathrm{kg}$ of caffeic acid showed significant tail flick latency (Gamaro et al., 2011). Analgesic effect of caffeic acid was also tested with formalin-induced nociception. Formalin test, one of the method to measure ability of a substance to prevent moderate continuous pain generated by injured tissue (Higgs et al., 2013). Treatment of $5,10,30$ and $100 \mathrm{mg} / \mathrm{kg}$ caffeic acid did not give any prevention at the early phase (neurogenic). However, at late phase (inflammatory), the antinociception was significantly increased.

Chrysin is a common flavonoid of propolis, honey and plants. Protective effect against cancer, antitumor, antihypertensive, anti-inflammatory and antiapoptotic effects are among biological properties of chrysin (Samarghandlan and Borji 2014; Shin et al., 1999). Previous study showed that chrysin cause analgesia at same effect as morphine. Besides, formalin test carried out prove significant analgesic effect of chrysin (50 and $100 \mathrm{mg} / \mathrm{kg}$ ) at later phase. $150 \mathrm{mg} / \mathrm{kg}$ chrysin however, showed significant analgesic effect at both early and late phase of formalin test. These results indicate that chrysin analgesic properties might affect like centrally acting drug (Bannon and Malmberg, 2007). Besides, analysis of noradrenalin and corticosterone level in serum also showed significant reduction in chrysin treated-rats, indicating low nociception or pain (Farkhondeh et al., 2015).

To date, there is no research conducted to investigate potential effect of apigenin in reducing morphine tolerance. However, apigenin showed analgesic activity and possible relationship to opioid system. Based on analgesic study of Orbignya speciosa Mart., apigenin isolated from dichloromethane extract of the plant showed significant analgesic effect in acetic acid-induced writhing test, similar to morphine-treated mice (Martins Gomes Pinheiro et al., 2012). Analgesic effect was also observed on mice in formalin test, in which the effect was similar with morphine-treated mice at first phase of the test. Furthermore, hot plate test conducted on mice treated with opioid receptor antagonist (naloxone) before injection of dichloromethane extract or apigenin showed reversal of analgesic effect. This shows that the effect of apigenin and dichloromethane extract (which also contain apigenin) may have involved in opioid system. Thus, apigenin can be potential compound in treating morphine tolerance.

Quercetin is another common bioactive compound in honey, as it is the most abundant flavonoid in plant. In a study of morphine tolerance and dependence, quercetin showed inhibition of analgesia by naloxone (Naidu et al., 2003). Ability of quercetin to reverse morphine tolerance was also proved by chronic treatment of quercetin. 25 and $50 \mathrm{mg} / \mathrm{kg}$ quercetin together with morphine reversed the tolerance to analgesic effect of morphine. More interestingly, in attempt to find out possible mechanism underlying the reversal of tolerance, result indicated that the reversal might due to suppression of nitric oxide synthase activity and thus reducing production of nitric oxide. Previous research also had shown that quercetin downregulate expression of nitric oxide synthase (Raso et al., 2001).

Other than in citrus fruits, naringenin also contain in honey. Study reports naringenin to have analgesic effect in inhibiting neuropathic pain on rats (Kaulaskar et al., 2012; Hu and Zhao, 2014). The result also demonstrates that narigenin reduced lipid peroxidation and nitric oxide. However, there is no study carried out to investigate possible opioid-related action of naringenin and its ability to reduce morphine tolerance. Luteolin, another flavonoid contain in honey, are reported to have analgesic activities in acetic acid-induced writhing and formalin test (Carvalho and Carvalho, 2001). Plants extract of Cassia siamea Lam containing luteolin showed significant analgesic effect in hot plate test, in which the flavonoid had contributed to the plant analgesic activity (Ntandou et al., 2010). Interestingly, in a study of opioid mechanism of medicinal plant Vitex agnuscactus $\mathrm{L}$, it is found that its flavonoid luteolin binded to MOR (Webster et al., 2011). This finding is supported by another study of antinociception, in which the analgesic effect of luteolin is blocked by MOR antagonists (Backhouse et al., 2008).

\section{CONCLUSION}

Honey brings a lot of health benefits to human health by its bioactive compounds. Several bioactive compounds were found to show significant analgesic activities. Some of them are proven to reduce tolerance to morphine. Hence, by these evidences, honey can be a promising natural solution in curing morphine tolerance among chronic morphine users by the synergistic effects of the flavonoids and phenolic acids. 


\section{CONFLICT OF INTERESTS}

The authors declared no conflict of interest with respect to the authorship and/or publication of thus paper.

\section{REFERENCES}

Abd. Aziz CB, Ahmad R, Mohamed M, Wan Yusof WN. The effects of Tualang honey intake during prenatal stress on pain responses in the rat offsprings. European Journal of Integrative Medicine, 2013;5:326331 .

Abdel-Zaher AO, Abdel-Rahman MS, Elwasei FM. Blockade of nitric oxideoverproduction and oxidative stress by Nigella sativa oil attenuates morphine-induced tolerance and dependence in mice. Neurochem. Res. 2010;35:1557-1565.

Ahmed J, Prabhu ST, Raghavan GSV, Ngadi M. Physicochemocal, rheological, calorimetric and dielectric behavior of selected Indian honey. J Food Eng, 2007;29:1207-13.

Alvarez-Suarez JM, Giampieri F, Battino M. Honey as a source of dietary antioxidants:Structures, bioavailability and evidence of protective effects against human chronic diseases. Curr Med Chem, 2013;20(5):621-638.

Alzubier AA, Okechukwu PN. 2011. Investigation of antiinflammatory, antipyretic and analgesic effect of yemeni sidr honey. International Scholarly and Scientific Research and Innovation, 2011; $5(8): 41-46$.

Backhouse N, Delporte C, Apablaza C, Farias M, Goity L, Arrau S, et al. Analgesic activity of Buddleja globosa (matico) in several models of pain. J Ethnopharmacol, 2008;119:160-5.

Bannon AW, Malmberg AB, Models of nociception: hot plate, tail flick, and formalin tests in rodents. Curr. Protoc. Neurosci, 2007;41: 891-896.

Berrocoso E, Sanchez-Blazquez P, Garzon J,Mico, JA. Opiates as Antidepressants. Current Pharmaceutical Design. 2009;15:1612-1622. Boroumand , Zamani MM, Saeedi M, Rouhbakhshfar O, Motlagh SRH, Moghaddam FA. Post tonsillectomy pain: can honey reduce the analgesic requirements?. Anesthesiology and Pain Medicine, 2013;3(1):198-202.

Carvalho GJA, Carvalho ME. Diterpenes, triterpenes and steroides from flowers of Wedelia paludosa. Quimica Nova, 2001; 24:2426.

Chao PC, Hsu CC, Yin MC. Anti-inflammatory and anticoagulatory activities of caffeic acid and ellagic acid in cardiac tissue of diabetic mice. Nutrition and Metabolism, 2009;6(33):1-8.

Das A, Datta S, Mukherjee S, Bose S, Ghosh S, Dhar P. Evaluation of antioxidative, antibacterial and probiotic growth stimulatory activities of Sesamun indicum honey containing phenolic compounds and lignans. LWT- Food Science and Technology, 2015;61:244-250.

DuPen A, Shen D, Ersek M. Mechanisms of opioid-induced tolerance and hyperalgesia. Pain Management Nursing, 2007;8(3):113121

Farkhondeh T, Samarghandian S, Azimin-Nezhad M, Samini F. Effect of chrysin on nociception in formalin test and serum levels of noradrenalin and corticosterone in rats. Int J Clin Exp Med, 2015;2:24652470 .

Fauzi AN, Norazmi MN, Yaacob NS. Tualang honey induces apoptosis and disrupts the mitochondrial membrane potential of human breast and cervical cancer cell lines. Food and Chemical Toxicology, 2011;49:871-878.

Gamaro GD, Suyenaga E, Borsoi M, Lermen J, Pereira P, Ardenghi P. Effect of Rosmarinic and Caffeic Acids on Inflammatory and Nociception Process in Rats. ISRN Pharmacology, 2011;1-6.

Gheldof N, Engeseth N. Antioxidant capacity of honeys from various floral sources based on the determination of oxygen radical absorbance capacity and inhibition of in vitro lipoprotein oxidation in human serum samples. Journal of Agricultural and Food Chemistry, 2012;50:3050-3055

Gheldof N, Wang XH, Miller NJ, Engeseth J. Agric. Food Chem, 2002;50:5870.
Goldberg R. 2014. Drugs across the spectrum. Belmont, USA: Cengage Learning.

Gunduz A, Eraydin I, Turkmen S, Kalkan OF, Turedi S, Eryigit U, Ayar A. Analgesic effects of mad honey (grayanotoxin) in mice models of acute pain and painful diabetic neuropathy. Human and Environmental Toxicology, 2014;33(2):130-135.

$\mathrm{Hu}$ CY, Zhao YT. Analgesic effects of naringenin in rats with spinal nerve ligation-induced neuropathic pain. Biomedical Reports, 2014;2:569-573

Higgs J, Wasowski C, Loscalzo LM, Marder M. In vitro binding affinities of a series of flavonoids for m-opioid receptors: analgesic effect of the synthetic flavonoid 3,3-dibromoflavanone in mice. Neuropharmacology, 2013;72:9-19.

Johnston JE, Sepe HA, Miano CL, Brannan RG, Alderton AL. Honey inhibits lipid oxidation in ready-to-eat ground beef patties. Meat Science, 2005;70(4):627-631

Kaulaskar S, Bhutada P, Rahigude A, Jain D, Harle U. Effect of naringenin on alldynia and hyperalgesia in rats with chronic constriction injury-induced neuropathic pain. Journal of Chinese Integrative Medicine, 2012;30(12):1482-1489.

Khalil MI, Alam N, Moniruzzaman M, Sulaiman SA, Gan SH. Phenolic acid composition and antioxidant properties of malaysian honeys. Journal of Food Science, 2011;76(6):921-928.

Kosten TR, George TP. The neurobiology of opioid dependence: implications for treatment. Science and Practice Perspectives, $2002 ; 13-21$

Kruger L. 2001. Methods in pain research. Florida, USA: CRC

Press.

Lees R, Lingford-Hughes A. Neurobiology and principles of addiction and tolerance. Medicine, 2012;40(12): 633-636.

Liu M, Song S, Li H, Jiang X, Yin P, Wan C, Liu X, Liu F, Xu J. The protective effect of caffeic acid against inflammation injury of primary bovine mammary epithelial cells induced by lipopolysaccharide. J. Dairy Sci., 2014;97:2856-2865.

Mansouri MT, Naghizadeh B, Ghorbanzadeh B. Ellagic acid enhances morphine analgesia and attenuates the development of morphine tolerance and dependence in mice. European Journal of Pharmacology, 2014;741:272-280.

Mansouri MT, Naghizadeh B, Ghorbanzadeh B. Ellagic acid enhances the analgesic action of venlafaxine in mouse acetic acidinduced pain: An isobolographic analysis. Pharmacological Reports, 2015;67:473-477.

Manyi-Loh CE, Clarke AM, Ndip RN. Identiication of volatile compounds in solvent extracts of honeys produced in South Africa. African Journal of Agricultural Research, 2011;6(18):4327-4334

Mao J, Sung B, Ji R, Lim G. Neuronal apoptosis associated with morphine tolerance: Evidence for an opioid-induced neurotoxic mechanism. The Journal of Neuroscience, 2002;22(17):7850-7861.

Martin Gomez Pinheiro, M., Boylan, F. and Fernandes, P.D. 2012. Analgesic effect of the Orbignya speciosa Mart. (Babassu) leaves: Evidence for the involvement of apigenin. Life Sciences, 91, 293-300.

Mayer DJ, Mao J. Mechanism of opioid tolerance: A current view of cellular mechanisms. Pain Forum, 1999;8(1):14-18.

Mayer A, Slezak V, Takac P, Olejnik J. Majtan J. Treatment of nonhealing leg ulcers with honeydw honey. Journal of Tissue Viability, 2014;23:94-97.

Mehrotra A, Shanbhag R, Chamallamudi MR, Singh VP, Mudgal J. Ameliorative effect of caffeic aicd against inflammatory pain in rodents. European Journal of Pharmacology, 2011;666:80-86.

Meotti FC, Luiz AP, Pizzolatti MG, Kassuya CAL, Calixto JB, Santos ARS. Analysis of the analgesic effect of the flavonoid myricitrin: evidence for a role of the L-arginine- nitric oxide and protein kinase $\mathrm{C}$ pathways. J. Pharmacol. Exp. Ther, 2006;316:789-796.

Mohamad N, Ismail R, Abdul Latif AZ, Mohamad M, Toriman ME. 2014. Terapi penggantian methadon: Penderitaan kebergantungan opiat yang boleh diubati. Kuala Terengganu, Terengganu: Penerbit UniSZA. 
Naidu PS, Singh A, Joshi D, Kulkarni SS. Possible mechanisms of action in quercetin reversal of morphine tolerance and dependence. Addiction Biology, 2003;8:327-336.

Narita M, Suzuki M, Narita M, Niikura K, Nakamura A, Miyatake M, Yajima Y. Suzuki T. M-opioid recepote internalizationdependent and in-dependent mechanisms of the development of tolerance to $\mu$-opioid receptor agonists: Comparison between etorphine and morphine. Neuroscience, 2006;138:609-619.

Nsonde Ntandou GF, Bnzouzi JT, Mbatchi B, Elion-Itou RDG, Etou-Ossibi AW, Ramos S, BenoitVical F, Abena AA, Ouamba JM. Analgesic and anti-inflammatory effects of Cassia siamea Lam. stem bark extracts. Journal of Ethnopharmacology, 2010;127:108-111.

Owoyele BV, Adenekan OT, Soladoye AO. Effects of honey on inflammation and nitric oxide production in Wistar rats. Zhong Xi Yi Jie He Xue Bao, 2011;9(4):447-452.

Pyrzynska K. Biesaga M. Analysis of phenolic acids and flavonoids in honey. Trends In Analytical Chemistry, 2009;28(7):893-902.

Raso GM, Meli R, Di Carlo G, Pacilio M, Di Carlo R. Inhibition of inducible nitric oxide synthase and cyclooxygenase-2 expression by flavonoids in macrophage J774A.1. Life Sci, 2001;68:921931.

Richard J. Honey and healing through the ages. Journal of Apiproduct and Apimedical Science, 2009;1(1):2-5.

Samarghandlan S, Borji A. Anticarcinogenic effect of saffron (Crocus sativus L.) and its ingredients. Pharmacognosy Res, 2014;6:99107.

Santos ARS, De Campos ROP, Miguel OG, Cechinel-Filho V, Yunes RA, Calixto J.B. The involvement of $\mathrm{Kq}$ channels and $\mathrm{G}$ protein in the analgesic action of the gallic acid ethyl ester. European Journal of Pharmacology, 1999;379:7-17.

Sato T, Miyata G. The nutraceutical benefit, part III:honey. Nutrition, 2000;16(6):468-469.

Schildhaus N, Trink E, Polson C, DeTolla L, Tyler BM, Jallo GI, Tok S, Guarnieri M. Thermal latency studies in opiate-treated mice. J Pharm Bioallied Sci., 2014;6(1):43-47.

Sherlock O, Dolan A, Athman R, Power A, Gethin G. Cowman S. Comparison of the antimicrobial activity of Ulmo honey from Chile and Manuka honey against methicillin-resistant Staphylococcus aureus, Escherichia coli and Pseudomonas aeruginosa. BMC Complement Altern Med, 2010;10(47):5.
Shi JS, Kim KS, Kim MB, Jeong IJ, Kim HBK. Synthesis and hypoglycemic effect of chrysin derivatives. Bioorg Med Chem Lett, 1999;9:869-74.

Skrabalova J, Drastichova Z, Novotny J. Morphine as a Potential Oxidatie Stress-Causing Agent. Mini-Reviews In Organic Chemistry, 2013;10:376-373.

Tornuk F,Karaman S, Ozturk I, Toker OS, Tastemur B, Sagdic O, Dogan M, Kayacier A. Quality characterization of artisanal and retail Turkish blossom honeys: Determination of physicochemical, microbiological, bioactive properties and aroma profile. Industrial Crops and Products, 2013;46:124-131.

Vidyalakshmi K, Kamalakannan $\mathrm{P}$, Viswanathan $\mathrm{S}$, Ramaswamy S. Analgesic effect of certain dihydroxy flavones in mice. Pharmacol. Biochem. Behav., 2010;96(1):106.

Yimam, M., Brownell, L., Hodges, M. and Jia, Q. 2012. Analgesic effects of a standardised bioflavonoid composition from scutella baicalensis and acacia catechu. J Diet Suppl, 9, 155-156.

Yoburn BC, Gomes BA, Rajashekara V, Patel C, Patel M. Role of G(i)alpha2-protein in opioid tolerance and mu-opioid receptor downregulation in vivo. Synapse, 2003;4:109-11.

Webster DE, He Y, Chen SN, Pauli GF, Farnsworth NR, Wang ZJ. Opioidergic mechanisms underlying the actions of Vitex agnus-castus L. Biochem Pharmacol, 2011;81:170-7.

White J.W. 1962. Composition of American Honeys. USDA Washington DC, USA: Agricultural Research Service.

White Jr. JW. Detection of honey adulteration by carbohydrate analysis. Journal of the Association of Official Analytical Chemists, 1980;63(1):11-18.

\section{How to cite this article:}

Zakaria NH, Ahmad NZ, Hashim SN, Mohd Adnan LH, Shariff MHM, Mohamad N, Mat KC, Abu Bakar NH. Analgesic effect of honey bioactive compounds and its role in reducing morphine tolerance. J App Pharm Sci, 2015; 5 (11): 146-150. 